\title{
FUTURE DIRECTIONS IN POSTAL REFORM
}




\section{Topics in Regulatory Economics and Policy Series}

\section{Michael A. Crew, Editor}

Center for Research in Regulated Industries

Graduate School of Management, Rutgers University

Newark, New Jersey, U.S.A.

\section{Previously published books in the series:}

Abbott, T. A.:

Health Care Policy and Regulation

Goff, B.:

Regulation and Macroeconomic Performance

Coate, M.B. and Kleit, A.N.:

The Economics of the Antitrust Process

Franz, R. S.:

$X$-Efficiency: Theory, Evidence and Applications (Second Edition)

Crew, M.:

Pricing and Regulatory Innovations Under Increasing Competition

Crew, M., and Kleindorfer, P.R.:

Managing Change in the Postal Delivery Industries

Awerbuch, S. and Preston, A.:

The Virtual Utility

Gabel, D. and Weiman, D.:

Opening Networks to Competition: The Regulation and Pricing of Access

Zaccour, G.:

Deregulation of Electric Utilities

Young, W.:

Atomic Energy Costing

Crew, M.:

Regulation Under Increasing Competition

Crew, M.A. and Kleindorfer, P. R.:

Emerging Competition in Postal and Delivery Services

Cherry, B.A.:

The Crisis in Telecommunications Carrier Liability:

Historical Regulatory Flaws and Recommended Reform

Loomis, D.G. and Taylor, L. D.:

The Future of the Telecommunications Industry:

Forecasting and Demand Analysis

Alleman, J. and Noam, E.:

The New Investment Theory of Real Options and its

Implications for Telecommunications Economics

Crew, M. and Kleindorfer, P. R:

Current Directions in Postal Reform

Lehman, D. E. and Weisman, D. L.:

The Telecommunications Act of 1996:

The "Costs" of Managed Competition

Crew, M. A.:

Expanding Competition in Regulated Industries 


\section{FUTURE DIRECTIONS IN POSTAL REFORM}

edited by

Michael A. Crew

Center for Research in Regulated Industries

Graduate School of Management

Rutgers University

Newark, New Jersey, U.S.A.

and

Paul R. Kleindorfer

Risk Management and Decision Process Center

The Wharton School

University of Pennsylvania

Philadelphia, Pennsylvania, U.S.A.

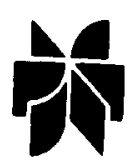

Springer Science+Business Media, LLC 


\section{Library of Congress Cataloging-in-Publication Data}

Future directions in postal reform / edited by Michael A. Crew and Paul R. Kleindorfer.

p. $\mathrm{cm}$. -- (Topics in regulatory economics and policy series)

"Eighth Conference on Postal and Delivery Economics: "Future Directions in Postal

Reform," held in Vancouver Canada, June 7-10, 2000"--Pref.

Includes bibliographical references.

ISBN 978-1-4613-5670-7 ISBN 978-1-4615-1671-2 (eBook)

DOI 10.1007/978-1-4615-1671-2

1. Postal service--Congresses. 2. Postal service--Management--Congresses. 3. Postal service--Automation--Congresses. 4. Postal service--Cost control--Congresses. 5. Postal service--Law and Legislation--Congresses. 6. Postal service--International

cooperation--Congresses. I. Crew, Michael A. II. Kleindorfer, Paul R. III. Conference on Postal and Delivery Economics (8th : 2000 : Vancouver, Canada) IV. Topics in

regulatory economics and policy.

HE6011 .F88 2000

$383^{\prime} \cdot 24--d c 21$

00-053088

Copyright ${ }^{\oplus} 2001$ by Springer Science+Business Media New York Originally published by Kluwer Academic Publishers in 2001

Softcover reprint of the hardcover 1st edition 2001

All rights reserved. No part of this publication may be reproduced, stored in a retrieval system or transmitted in any form or by any means, mechanical, photocopying, recording, or otherwise, without the prior written permission of the publisher, Springer Science+Business Media, LLC. 


\section{CONTENTS}

Authors

vii

Sponsors

$i x$

Preface and Acknowledgements

$x i$

\section{Regulation and Liberalization}

1. Difficulties of Deregulation When Wage Costs are the Major Cost 3 Michael L. Wachter, Barry T. Hirsch, and James W. Gillula

2. Estimation of the Potential Impact of Cross-Border Liberalization Ian Reay, Richard Robinson, Frank Rodriguez, and Paul Liddiard

3. A Critique of the Theory of Incentive Regulation Michael A. Crew and Paul R. Kleindorfer

4. Preparing the Postal Service's Rate Structures for Competition Robert W. Mitchell

5. Regulatory and Governance Changes in Liberalized, Commercialized Postal Environments

Robert M. Campbell

\section{Universal Service Obligation}

6. Funding Universal Service Obligations:

The Costs of Liberalization

John C. Panzar

7. Whither the USO under Competitive Entry: A Microstructure Approach

Michael A. Crew and Paul R. Kleindorfer

8. Uniform Pricing and Postal Market Liberalization

Philippe De Donder, Helmuth Cremer, Jean-Pierre Florens, André Grimaud, and Frank Rodriguez

9. The Role of the Monopoly Product in the Cost of Universal Service 163 Michael D. Bradley and Jeff Colvin

10. The Regulatory Framework for Postal Markets in Germany Cara Schwarz-Schilling 


\section{Analysis of Demand and Cost}

11. An Analysis of Some Specific Cost Drivers in the Delivery Activity 197 Catherine Cazals, Jean-Pierre Florens, and Bernard Roy

12. Mail Use by Firms Marc DeRycke, Sarah Marcy, and Jean-Pierre Florens

13. The Demand for Direct Mail in Portugal Ricardo Goulão Santos and Sérgio Chilra Lagoa

14. Postal Profits Arise where People Are Gennaro Scarfiglieri and Vincenzo Visco Comandini

\section{International}

15. Reforming the Universal Postal Union James I. Campbell, Jr.

16. Reform in the Universal Postal Union and the World Trade Organization Mary S. Elcano and Anthony Alverno

17. GATS and the Postal Sector: The Next Round of Negotiations Hilke Smit

\section{Competition Law}

18. The Significance of the Microsoft Antitrust Litigation for Postal Services Operators William E. Kovacic

19. Market Definition in EC Competition Law concerning Postal Services Richard Eccles

\section{Future Technologies}

20. Lifetime Addresses: A New Postal Paradigm for the $21^{\text {st }}$ Century 365 Camille Bradford and Jack Mayer

21. Legislation Relating to Electronic Web Commerce Created at the 375 European Union Level Pekka Leskinen 


\section{AUTHORS}

Anthony Alverno, Attorney, International \& Ratemaking Law Section, United States Postal Service

Camille Bradford, Vice President, Lifetime Addressing, Inc.

Michael D. Bradley, Professor of Economics, George Washington University

James I. Campbell, Jr., Attorney

Robert M. Campbell, Dean of Arts and Professor of Political Science, Wilfrid Laurier University, Waterloo, Ontario, Canada

Catherine Cazals, Assistant Professor of Economics, GREMAQ and IDEI, University of Toulouse I

Jeff Colvin, Manager, Marketing Cost Analysis, United States Postal Service

Helmuth Cremer, Professor of Economics, GREMAQ and IDEI, University of Toulouse and Institut Universitaire de France

Michael A. Crew, Professor of Economics and Director of the Center for Research in Regulated Industries, Graduate School of Management, Rutgers University

Philippe De Donder, Assistant Professor of Economics, GREMAQ and IDEI, University of Toulouse

Marc De Rycke, La Poste

Richard Eccles, Partner, Cameron McKenna

Mary S. Elcano, Partner, Brown \& Wood LLP, former General Counsel and Executive Vice President for Human Resources, Unites States Postal Service

Jean-Pierre Florens, Professor of Mathematics, GREMAQ and IDEI, University of Toulouse

James W. Gillula, Standard \& Poor's DRI

André Grimaud, Université des Sciences Sociales, IDEI - Institut D'Economie Industrielle and University of Toulouse I

Barry T. Hirsch, E.M. Stevens Professor of Economics, Trinity University

Paul R. Kleindorfer, Universal Furniture Professor of Economics and Decision Sciences and Co-Director of Center for Risk Management, Wharton School, University of Pennsylvania 
William E. Kovacic, Professor, National Law Center, George Washington University

Sérgio Chilra Lagoa, Economist, CTT-Correios de Portugal S.A.

Pekka Leskinen, General Counsel, Finland Post Ltd.

Paul Liddiard, Operational Research Analyst, The Post Office

Sarah Marcy, Researcher, Université des Sciences Sociales, IDEI Institut D'Economie Industrielle and University of Toulouse I

Jack Mayer, President, Lifetime Addressing, Inc.

Robert W. Mitchell, Special Assistant to the Commission, United States Postal Rate Commission

John C. Panzar, Louis W. Menk Professor of Economics, Northwestern University

Ian Reay, Liberalisation and Monopoly Policy Manager, The Post Office

Richard Robinson, Head of Operational Research, The Post Office

Frank Rodriguez, Head of Economics, Commercial and Business Strategy Department, The Post Office

Bernard Roy, Head of the Economic Modelling Department, La Poste

Ricardo Goulão Santos, Economist, CTT-Correios de Portugal S.A.

Gennaro Scarfiglieri, Manager, Market and Competitors Unit, Poste Italiane $\mathrm{SpA}$

Cara Schwarz-Schilling, Head of Section 'Economics of Regulating Postal Markets,' Regulatory Authority for Telecommunications and Post

Hilke Smit, Economist, Communications, Postal Services and Logistics, WIK - Wissenschaftliches Institut fuer Kommunikationsdienste $\mathrm{GmbH}$

Vincenzo Visco Comandini, Director for Strategies and Market Unit, Poste Italiane SpA

Michael L. Wachter, William B. Johnson Professor of Law and Economics, Institute for Law and Economics, University of Pennsylvania 


\section{SPONSORS}

CRRI, Graduate School of Business, Rutgers University

Center for Risk Management, Wharton School, University of Pennsylvania

Royal Mail/U.K. Post Office

Canada Post Corporation

Deutsche Post

Federal Express

La Poste

R.R. Donnelley \& Sons Company

United Parcel Service

CTT Correios (Portuguese Post)

Pitney Bowes

PricewaterhouseCoopers

Siemens Electrocom

Australia Post

Sweden Post

Finland Post

United States Postal Rate Commission

Correos y Telégrafos (Spanish Post)

ICP - Instituto das Comunicaçoes de Portugal

Linx (A Division of A.T. Kearney)

Post Danmark

United States Postal Service

Poste Italiane

New Zealand Post

National Association of Letter Carriers

Association for Postal Commerce

Postal Services International

Finland Ministry of Transport and Communications 


\section{PREFACE AND ACKNOWLEDGEMENTS}

This book arises out of the Eighth Conference on Postal and Delivery Economics: "Future Directions in Postal Reform," held in Vancouver Canada, June 7-10, 2000. Leading practitioners, postal administrations, and the courier industry, as well as a number of regulators, academic economists, mailers, consultants, and lawyers came together to examine some of the major policy and regulatory issues facing the industry. Issues addressed included international postal policy; the universal service obligation; regulation; competition, entry, and the role of scale and scope economies; the nature and role of cost analysis in postal service; productivity; interaction of law and economics; future technologies; and service standards.

The conference and the book follow our earlier conferences. In 1990, a conference was held at Coton House, Rugby, England, July 22-25, 1990, in honor of the one hundred and fiftieth anniversary of the Penny Post and the contributions of Sir Rowland Hill. The ensuing book, Competition and Innovation in Postal Services, was published by Kluwer Academic Publishers in 1991. In 1992, Regulation and the Evolving Nature of Postal and Delivery Services: 1992 and Beyond was held at Village PTT, La Londe les Maures, France, on March 18-21, 1992. This conference resulted in Regulation and the Nature of Postal and Delivery Services, published by Kluwer in 1993. Both conferences were recognized by the European Express Organization with the Hermes Award 1992 at its annual award dinner in Munich on June 22, 1992. The first workshop, The Workshop on Postal and Delivery Economics, was held June 23-26, 1993 in Daun, Germany. In 1994 a Conference in Stockholm, Sweden, May 18-21,1994, and a workshop, in Hakone, Japan, June 1-4, 1994 combined to produce the volume Commercialization of Postal and Delivery Services, published by Kluwer in 1995. A workshop was held in Naantali, Finland, June 7-10, 1995. A Conference was held in Monterey, California, May 22-25, 1996, and resulted in the book Managing Change in The Postal and Delivery Industries, published by Kluwer in 1996. The next book, Emerging Competition in Postal and Delivery Services was a direct result of the Fifth and Sixth Conferences on Postal and Delivery Economics: The Evolving Structure of Postal and Delivery Industries held in Helsingor, Denmark, June 11-14, 1997; Emerging Competition in the Postal and Delivery Sectors held in Montreux, Switzerland, June 17-20, 1998. These combined to produce the book Emerging Competition in the Postal and Delivery Services. The Seventh Conference on Postal and Delivery Economics, Current Directions in Postal Reform, was held in Sintra, Portugal, June 2326, 1999. This resulted in the book Current Directions in Postal Reform 
The 2000 conference was made possible by the support of the following organizations: CRRI-Center for Research in Regulated Industries, Graduate School of Business, Rutgers University; Center for Risk Management and Decision Processes, The Wharton School, University of Pennsylvania; Royal Mail/U.K. Post Office; Canada Post Corporation; Deutsche Post; La Poste; R.R. Donnelley \& Sons Company; United Parcel Service; Federal Express; CTT Correios (Portuguese Post); Pitney Bowes; PricewaterhouseCoopers; Siemens Electrocom; Australia Post; Sweden Post; Finland Post; ICP-Instituto das Comunicaçoes de Portugal; Linx (A Division of A.T. Kearney); Post Danmark; Correos y Telégrafos (Spanish Post); United States Postal Rate Commission; United States Postal Service; Poste Italiane; New Zealand Post; Association for Postal Commerce; National Association of Letter Carriers; Postal Services International; Finland Ministry of Transport and Communications. We would like to thank sponsors not only for financial support, but also for their advice and encouragement, and for serving on the organizing committee. In particular, we would like to thank John Allen, Mary Bundy, James Campbell, Catherine Churchard, Ken Churchill, Robert Cohen, Jeff Colvin, João Confraria, Gene Del Polito, John Dolling, Edward Gleiman, Rob Gray, John Haldi, Gary Jensen, Peter Johnson, Matti Linnoskivi, Lynn Malcolm, Rohan Malhotra, José Marcos, Heikki Nikali, Virpi Palo, Alberto Pimenta, Bill Price, Sarah Prosser, Oluf Raldorf, David Rawnsley, Ian Reay, Kevin Richardson, Frank Rodriguez, James Sauber, John Schmidt, Christian Schunck, Nancy Sparks, Börge Spong, David Storer, Joëlle Toledano, David Treworgy, Vincenzo Visco-Commandini, Sture Wallander, Tim Walsh, and Anton van der Lande.

The host country plays an important role in these conferences. This year's conference, the Eight Conference on Postal Delivery Economics, benefited greatly from the efforts of our hosts Canada Post. Bill Price provided advice, reminders, and assistance on numerous occasions in his role as Canada Post's representative on the organizing committee. In addition, Louis O'Brien and Gerard Power were helpful to us with their advice and assistance.

In the tradition of these conferences we very much enjoyed the speeches by three distinguished executives in the postal sector. We thank John M. Nolan, Deputy Postmaster General, United States Postal Service; Luis Jimenez, Vice President of Global Growth and Futures Strategy, Pitney Bowes; and Peter T. McInenly, Q.C., Vice President-Strategic Planning, Canada Post Corporation. Each, at his dinner speech, provided a unique perspective on the problems facing postal and delivery networks. 
Finally, we must thank Jeremy T. Guenter, Administrative Assistant in the Center for Research in Regulated Industries, for his efforts in making this book possible. He performs his typesetting tasks in addition to his day to day administrative tasks. These include administrative support for all of the Center's conferences and workshops. This is the third book he has typeset in a little over a year at the Center. He was of considerable assistance to us several ways, particularly the development of the Style Instructions, which were a great help in helping us meet the tighter deadlines and generally improved the production process. We would like to thank him not only as editors but on behalf of the authors too. As an extension of his work on the book this year he is developing a research tool available to all through the CRRI web site. This will provide access to the many references used in this and other postal books in the series. Researchers will not only be able to use this as a means of searching the literature but also be able to download them for listing in their papers. This is a continuing project involving frequent updating of the database. Visit us on the web at http://www.rci.rutgers.edu/ crri.

The usual disclaimers are applicable. In particular, the views expressed are the views of the authors and are not necessarily those of the sponsors.

Michael A. Crew

Paul R. Kleindorfer 